

\section{EXPEDIENTE}

Universidade do Estado do Rio de Janeiro - UERJ

Instituto de Estudos Sociais e Políticos - IESP

\section{CADERNOS DE ESTUDOS SOCIAIS E POLÍTICOS}

www.e-publicacoes.uerj.br/index.php/CESP

\section{COMITÊ EDITORIAL}

Giovana Esther Zucatto, IESP-UERJ

Helio Cannone, IESP-UERJ

Marcelo Borel, IESP-UERJ

Marcia Rangel Candido, IESP-UERJ

Marina Rute Pacheco, IESP-UERJ

Mariane Silva Reghim, IESP-UERJ

Paulo Joaquim Da Silva Rodrigues, IESP-UERJ

Raul Nunes de Oliveira, IESP-UERJ

\section{CAPA, LAYOUT E DIAGRAMAÇÃO}

Marcia Rangel Candido

Raul Nunes de Oliveira

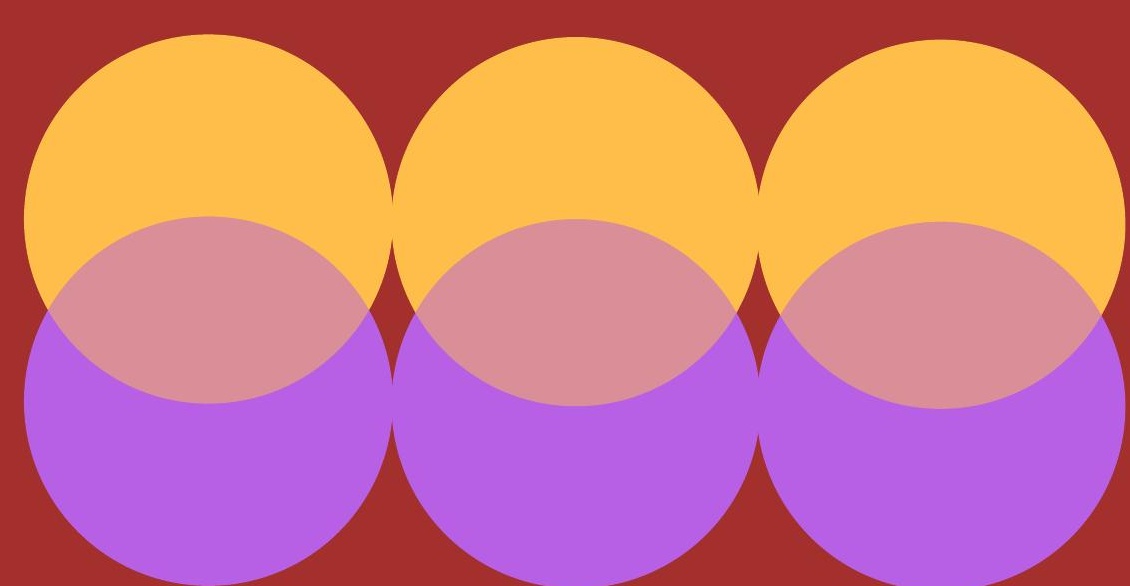


Apresentação

Mariane Silva Reghim e Marcelo Borel

Dossiê

As Expressões Do Racismo Institucional Nas Universidades Federais Do

Estado Do Rio De Janeiro: Mulheres Negras Trabalhadoras e Intelectuais

Cibele da Silva Henriques

Ressignificando As Raças: Os Deuses Pretos e Os Demônios Brancos No Discurso Nacionalista Preto Da Nação Do Islã nos Estados Unidos Da América

Rafael Filter Santos da Silva

Feminismo Negro e a Interseccionalidade de Gênero, Raça e Classe

Eunice Lea de Moraes Lucia Isabel Conceição da Silva

A Corporeidade e a Liberdade: Mulheres Negras e a Coragem De Ser

Joyce Gonçalves Restier da Costa Souza

\section{Artigos}

Os Governos Do PT e As Agências De Rating: Os Percalços De Treze Anos De Relação

Pedro Lange Netto Machado

Apropriação Cultural: Novas Configurações das Identidades na Era da Globalização

Bárbara Lopes Heleno e Rafaella Max Reinhardt

Resenha Crítica: O Segredo como Conceito Político: a propósito de Democracia e Segredo de Norberto Bobbio

Ronaldo Tadeu de Souza 


\title{
Ressignificando As Raças: Os Deuses Pretos e Os Demônios Brancos No Discurso Nacionalista Preto Da Nação Do Islã nos Estados Unidos Da América
}

Resignifying Races: Black Gods And White Devils In The Nation Of Islam's Black Nationalist Discourse In United States of America

\author{
Rafael Filter Santos da Silva ${ }^{1}$
}

\begin{abstract}
RESUMO
O presente artigo faz uma análise do discurso dos livros sagrados da Nação do Islã, que buscou reformular os sentidos das relações inter-raciais. Discutirei como as representações acerca do marcador social da diferença raça foram ressignificados pelo discurso de Elijah Muhammad, visando a uma reestruturação da situação social da população preta dos Estados Unidos da América.
\end{abstract}

PALAVRAS-CHAVE: representação; nacionalismo preto; raça; Estados Unidos da América.

\begin{abstract}
The present article analyzes the discourse of the sacred books of Nation of Islam, which aims to reformulate the meanings of inter-racial relations. It discusses how representations on social marker of difference race was resignified by Elijah Muhammad discourse with the objective of restructure black people social situation in United States of America.
\end{abstract}

KEY-WORDS: representation; black nationalism; race; United States of America.

1 Mestre em História pela Universidade Federal do Rio Grande do Sul. E-mail: rafilter1988@gmail.com 
Cadernos de Estudos Sociais e Políticos, Rio de Janeiro, vol. 7, nº 13, 2017

\section{INTRODUÇÃO}

“Vamos tentar ser nós mesmos primeiro e parar de tentarmos ser como o demônio. Homem Preto, você foi criado Preto. Você, homem Preto, é o primeiro e o último. Homem Preto pare de tentar ser branco"2 (MUHAMMAD, 1973: cap. 3, \8). O excerto revela-nos uma vontade de ruptura identitária e assunção de uma nova postura de aceitação de si. Vontade de ruptura, pois Elijah Muhammad, autor em questão, exorta seus interlocutores a renunciarem ao desejo de ser branco; de conformarem-se a concepção ontológica de sujeito erigida por uma outra raça que se pensa como padrão universal. Negar tal ontologia quebraria a suposta homogeneidade iluminista da pessoa humana, trazendo à tona uma nova forma de construção identitária que destaca a pluralidade e a fragmentação dos diferentes grupos e indivíduos. O ser humano criado preto ${ }^{3}$ por Alá deveria aceitar o marcador social da diferença associado à cor de sua pele para constituir-se subjetivamente. Classificação produzida socialmente, os marcadores categorizam os indivíduos, identificando-os em determinado nível com uma posição de privilégio/desvantagem social, o que acaba por influir sobre a organização das vivências de cada um (ZAMBONI, 2014). Ao assumir sua condição diversa daquela do branco, o Preto colocou em debate as instituições vigentes, preparadas para atender somente às demandas de seus "pais fundadores" euro-americanos.

O discurso nacionalista preto que fundamentou a identidade apregoada por Elijah procurou desbancar a branquitude, elemento basilar da identidade dos Estados Unidos da América. A

2 No original: "Let us try and be ourselves first and stop trying to be like the devil. Black man, you are created Black. You, Black man, are the first and the last. Black man stop trying to be white".

3 Usarei a palavra "Preto", realizando, portanto, tradução literal, em vez de "negro/Negro" quando me referir aos membros da Nação do Islã ou as ideias de seus livros religiosos, pois Elijah Muhammad emprega a expressão "Black man", demonstrando repúdio pelo termo "Negro" em seus textos. Segundo o dicionário Oxford (Oxford Dictionaries, 2016), a palavra "Negro", relacionada à cor da pele, proveio da língua espanhola, sendo os primeiros registros do século XVI. Na língua inglesa, o termo não se refere a uma cor em si (espectro de onda visível), mas apenas a uma cor de pele e à classificação racial associada a este traço físico. "Black" (Ibidem), por sua vez, de origem linguística germânica, refere-se à cor em si e à raça. Na língua portuguesa (Houaiss, 2009), a palavra "negro" é utilizada de forma semelhante ao "Negro" em inglês, sendo pouco empregada para referir-se a uma cor em si. "Preto", originado do latim, denomina (Ibidem) a cor em si, a raça e a cor da pele. Preferi, levando esses significados em consideração, usar "Preto" como tradução de "Black". "Negro" (português) e "Negro" (inglês) têm a mesma escrita e origem etimológica, mudando somente a pronúncia de forma sutil. Empregar "negro" no lugar de "Black" poderia gerar confusão no leitor. 
branquitude é, dentro de sociedades em que predomina a identidade da pessoa branca como padrão, o "lugar de privilégios simbólicos, subjetivos, objetivos, isto é, materiais palpáveis que colaboram para construção social e reprodução do preconceito racial” (CARDOSO, 2010: p. 611). Os privilégios brancos podem ser obtidos por não-brancos, colocando-os mais próximos da branquitude - por exemplo, através do enriquecimento econômico -, porém a falta da brancura dos traços fenotípicos barra o acesso aos níveis mais altos de privilégio. Numa sociedade estruturada dessa forma, o branco praticamente é sem cor e sem raça, pois, por ser o tipo paradigmático para o qual a sociedade foi planejada, não é marcado como outro, logo, não se pensa sobre como seus marcadores influenciam sua constituição subjetiva e sua inserção na sociedade. Estudos acerca da branquitude retiram o marcador "branco" de uma condição de invisibilidade, revelando seu status de hegemônico e de padrão imposto de normalidade, para criticá-lo. Conforme tempo e espaço, há distintas classificações raciais, logo, diferentes concepções de branquitude (GARNER, 2007). Nem todo movimento nacionalista preto é de cunho religioso, ou repudia o termo "negro", contudo todos questionam as representações calcadas na supremacia branca.

Os escritos de Elijah Muhammad, líder da Lost-Found Nation of Islam in America ${ }^{4}$ entre 1934 e 1975, discorrem sobre um mito de antropogonia, no qual se proclama a pessoa de tez preta sagrada e a branca é considerada obra do demônio Yakub. Ressignificou-se a identidade estereotipada daqueles negativamente conotados pelo simbolismo estadunidense acerca da raça: negro como ser infantil, perigoso, subcidadão, etc. A divinização procurou reformular o simbolismo atribuído à sua raça pelos brancos, retirando-se o afro-americano de uma condição de infra-humanidade para proclamá-lo descendente de deidades antigas, almejando romper privilégios. O discurso dos muçulmanos pretos alterava o sentido atribuído aos características raciais negros, agregando-lhes um tom positivo, ou seja, praticavam uma "strategy of uplift" (CORBOULD, 2009: p. 4), de soerguimento moral e

4 Nome completo da Nação do Islã, cuja tradução livre é: "Nação Perdida-encontrada do Islã na América". A genealogia pré-adâmica da Nação do Islã foi uma tentativa, de estipular uma origem diferente do inimigo. Repudiou-se a origem humana bíblica. Um Preto de terras asiáticas criara Adão e Eva para executar seus objetivos sórdidos de conquista do poder. A origem dos muçulmanos pretos estava em Alá e na Tribo de Shabazz, os quais não eram europeus, nem semitas. Assim como o mito ariano que buscava a fonte do gênero humano em terras asiáticas - Índia, principalmente, de onde teria vindo os arianos indo-europeus - desligadas dos mitos semíticos, a Nação do Islã afirmava que a origem da humanidade acontecera em um local ora chamado de Ásia Oriental, ora de África, em um paraíso distinto do Éden da Bíblia.

5 Tradução livre: "estratégia de exaltação/soerguimento". 
espiritual. Uma reconstrução do imaginário social para quebrar a representação do Preto como inferior, revigorando o corpo e a alma de sua gente, no intuito de fortalecer os Pretos para lutarem contra a marginalização social.

O presente artigo faz uma análise do discurso dos livros sagrados da Nação do Islã - I) Message to the Blackman in America (1965) II) The Fall of America (1973); III) Our saviour has arrived (1975) -, que buscou reformular os sentidos das relações inter-raciais num período da história dos Estados Unidos no qual vigoravam leis de segregação racial que impediam os não-brancos de exercerem cidadania plena. Discutiremos como as representações acerca do marcador social da diferença racial foram ressignificadas pelo discurso de Elijah Muhammad, visando a uma reestruturação da vida social da população preta. Esse movimento nacionalista preto dos Estados Unidos, do qual participaram figuras como o pugilista Muhammad Ali-Haj e Al-Hajj Malik AlShabazz - mais conhecido como Malcolm X - permaneceu atuante até a presente data.

\section{MOVIMENTOS NEGROS E NACIONALISMOS PRETOS}

Indicar surgimentos é algo difícil em História, porque embora pareça fato objetivo facilmente comprovável para o senso comum, nunca se sabe quem primeiro pensou uma ideia, ou praticou determinada ação. O historiador trabalha com fontes que se renovam através de novas descobertas e interpretações cujos registros contidos não revelam tudo. O que de alguma maneira não for registrado, se perderá no tempo, ausente de datas e comprovações. Desse modo, tentar dizer quando surgiu o nacionalismo preto é uma tarefa de grande dificuldade, pois os negros escravizados nem sempre tiveram acesso à escrita, ou, até mesmo, à preservação da memória por outras vias, devido à violência que atravessava suas vidas. Talvez nunca se saiba quem foi o primeiro nacionalista preto do mundo, entretanto, podemos apresentar certas informações sobre a história dessa ideia e dos movimentos por ela estimulados a partir de algumas referências bibliográficas que buscam estabelecer uma cronologia consoante suas interpretações. 
Pinkney (1976) acredita que manifestações de certas características do nacionalismo preto já estavam presentes em alguns movimentos do século XVI - primeira rebelião de trabalhadores escravizados em San Miguel de Gualdape, no território do que é hoje a Carolina do Sul, antes mesmo da legalização da escravidão nas Treze Colônias -, apesar de a maioria dos autores defenderem que o nacionalismo preto apareça no século XIX em território estadunidense. Diante das interdições de direitos e proibições de seus padrões culturais, os negros organizaram-se de modo a fortalecerem seus laços e lutarem por mudanças. A concentração em determinadas áreas urbanas e rurais, as quais, em diversas ocasiões, foram abandonadas pelos brancos, facilitou a formação de um espírito comunitário.

A solidariedade negra aparece nas conspirações de cativos, como a de 1773 em que os trabalhadores escravizados de Massachusetts reivindicaram liberdade para ganhar dinheiro e comprar passagem para a costa africana, onde se assentariam. Após a independência dos Estados Unidos da América, laços de solidariedade racial conceberam organizações negras - como a Free African Society of Philadelphia ${ }^{6}$, fundada em 1787 - de auxílio mútuo com organização cooperativa de propósitos variados. A Sociedade do Africano Livre da Filadélfia ajudava os doentes, as viúvas e os órfãos negros.

Perante a segregação em igrejas cristãs, Richard Allen montou a African Methodist Episcopal Church $^{7}$ na Filadélfia no final do século XVIII. Posteriormente, formaram-se outras igrejas que pregavam o Cristianismo de acordo com uma interpretação dos Evangelhos feita por negros. EssienUdon (1995) sublinha que essas eram ambientes de grande participação afro-americana, cujas lideranças eram independentes do controle branco. Igrejas eram importantes centros de convívio social, relevantes para a formação de uma identidade de grupo e de um pensamento autônomo.

Em 1796, a Sociedade Africana foi fundada. Ela incentivava a emigração dos negros, visando a formação de uma nação africana governada pela raça negra. Protestos contrários à escravização ocorreram, nos quais, por exemplo, afro-americanos enviaram petições ao Congresso se opondo a leis da Carolina do Norte que proibiam a manumissão de cativos em 1797. Negros livres da

6 Tradução livre: "Sociedade do Africano Livre da Filadélfia".

7 Tradução livre: "Igreja Metodista Episcopal Africana". 
Filadélfia, em 1800, elaboraram uma petição contra a escravização, o comércio escravista e o ato sobre cativos fugidos de 1793.

Victor Ullman (1971) acredita que o nacionalismo preto nos Estados Unidos tenha surgido com os esforços de Paul Cuffee (1759-1817), capitão de uma embarcação, nascido em uma ilha na costa de Massachusetts. Ele queria a emigração dos negros para a África; a abertura de rotas comerciais com aquele continente; extinção do comércio escravista e espalhar o Cristianismo entre os africanos.

Cuffee foi o primeiro afro-americano a ganhar um caso na justiça envolvendo direitos civis em nome da população negra. Recusou-se a pagar impostos durante a Revolução Americana. Ele entrou com uma petição contra o excesso de impostos cobrados dos negros, o que, no fim, resultou em uma lei declarando que negros livres tinham os mesmos direitos e privilégios que os brancos. Fundou escolas para promover a educação especialmente para crianças negras e indígenas.

Ao longo de suas viagens, participou da montagem de várias sociedades de auxílio mútuo entre negros. Ao conhecer Serra Leoa, interessou-se pela ideia de levar afro-americanos para povoar a região. Ela foi uma área da costa oeste africana para onde o Império Britânico mandou ex-cativos, para reduzir, por exemplo, o número de negros nas ruas de Londres. Cuffee tentou, sem sucesso, conseguir apoio do governo estadunidense para que um navio ficasse encarregado de levar afroamericanos para se estabelecerem em Serra Leoa. Sem financiamento público, ele não pôde realizar seu desejo.

Cuffee e outras lideranças negras fizeram oposição à Sociedade de Colonização Americana, essa, sim, recebeu apoio do governo. Acusavam-na de colocar em prática uma política de deportação de afro-americanos, pois negros que desejavam permanecer em solo estadunidense foram levados para África a mando de algum patrocinador, principalmente afro-americanos que reivindicavam direitos (PINKNEY, 1976).

O Negro Convention Movement ${ }^{8}$, surgido em 1817, também se opôs à Sociedade de Colonização Africana, pois defendia o auxílio mútuo e a emigração para o Canadá. Pregava o boicote a produtos feitos com mão de obra escravizada; era contra a escravidão e discriminação; não aceitava que os

8 Tradução livre: "Movimento da Convenção Negra". 
negros fossem chamados de "pessoas de cor" ou "africanos"; era contrário ao repatriamento na África, porque acreditava na imagem propalada pelo branco de um continente selvagem.

Um dos membros do Negro Convention Movement, Martin Robinson Delany (1812-1885), é intitulado, por autores como Scott (2012), o primeiro a publicar um livro nacionalista preto, no ano de 1852: "A condição, elevação, emigração e o destino da pessoa de cor dos Estados Unidos" . Médico descendente de chefes africanos escravizados, publicou sobre a questão negra em periódicos, fazendo parceria com Frederick Douglass. Opôs-se à Sociedade de Colonização Africana, pois pensava que ela estava transformando a Libéria numa colônia povoada por negros libertos, para sustentar o escravagismo, mantendo os alforriados distantes e impedindo manifestações. Entretanto, defendia a repatriação dos afro-americanos na África de uma maneira diferente da feita pela Sociedade de Colonização Africana. Acreditava que o afro-americano deveria sair de sua condição de subserviência nos EUA e ir assentar-se na África Oriental. Ansiava pela construção de uma ferrovia que conectasse todo continente africano. Usava como bordão a frase: “África para os africanos". Posteriormente, sustentou a ideia de assentamentos no Canadá, América Central e Caribe. Queria que negros fossem para um lugar em que brancos não comandassem suas vidas. Enfim, abandonou a postura emigracionista, todavia continuou trabalhando em prol da libertação do negro.

Outro defensor da emigração para a África foi Alexander Crummell (1819-1898). Ministro da Igreja Episcopal, estudou na Universidade de Cambridge por meio de financiamento de abolicionistas estadunidenses, tornando-se o primeiro negro a graduar-se naquela instituição. Viveu na Libéria, onde trabalhou na catequização dos africanos nativos. Pregou a ideia da emigração dos afro-americanos para a Libéria, local no qual realizariam a missão civilizacional negra. Os insucessos na África o fizeram retornar para os Estados Unidos, onde defendeu a ideia de uma economia autônoma negra e o acesso à educação. Trabalhou na American Negro Academy ${ }^{10}$, organização que prestava ajuda aos afro-americanos em busca de educação formal (MOSES, 2004).

Henry McNeal Turner (1834-1915) foi um bispo da Igreja Metodista Episcopal Africana, que serviu como capelão do exército da União durante a Guerra Civil estadunidense. Posteriormente

9 No original: "The Condition, Elevation, Emigration, and Destiny of the Colored People of the United States".

10 Tradução livre: "Academia do Negro Americano". 
envolveu-se com a política, ajudando a formar o Partido Republicano da Geórgia. No entanto, diante do fracasso do período da Reconstrução, do racismo estrutural que não esmaeceu e de ameaças da $\mathrm{Ku}$ Klux Klan, Turner assumiu uma postura emigracionista de retorno para África. Frente à declaração de inconstitucionalidade do ato de Direitos Civis de 1875 (previa tratamento igual em acomodações públicas, transporte público e acesso ao serviço de júri para todas as raças) pela Suprema Corte dos Estados Unidos da América, que afirmou ser inconstitucional a tentativa do governo de proibir a discriminação feita por pessoas e organizações privadas, Turner disse que o afro-americano não devia mais prestar lealdade ao país. Os negros deveriam realocar-se ou prepararem-se para o extermínio (ANGELL, 1992).

Turner apoiou o projeto de lei do Senador Matthew Butler, que exigia que o governo providenciasse transporte para fora do país para qualquer negro que desejasse se tornar cidadão de outro Estado. O projeto sofreu oposição de brancos - medo da perda de mão de obra barata - e de negros - receio de deportação de todos os afro-americanos. Organizou a International Migration Society $^{11}$, com o respaldo de empresários brancos, para auxiliar na emigração para África, Libéria principalmente.

Turner declarou que tinha o direito bíblico de acreditar que Deus era negro, pois todas as raças descrevem seus deuses como semelhantes a si, logo, o negro também poderia crer em um deus cujas características se parecessem com a sua. O bispo foi, portanto, uma das primeiras pessoas a representarem uma divindade de base cristã como negra.

Noble Drew Ali, cujo nome registrado fora Timothy Drew (1886-1929), é considerado o primeiro líder islâmico negro relevante a surgir nos Estados Unidos. Foi um dos tantos afroamericanos a trilharem o caminho para o Norte, no período das Grandes Migrações. Pregava um Islã heterodoxo, pois via nessa religião a possibilidade de inclusão racial. No Moorish Science Temple of America $^{12}$, a identidade racial possuía alta importância, porque Drew Ali acreditava que o autoconhecimento permitiria a salvação e a vitória sobre os opressores. Identificava-se como Mouro,

11 Tradução livre: "Sociedade de Migração Internacional".

12 Tradução livre: "Templo Americano da Ciência Moura". 
Asiático ou Mouro-americano. Fundou templos em Detroit, Pittsburgh, Filadélfia, Nova Iorque e Chicago.

Turbante amarelo e capa de fios dourados eram os trajes de Sufi Abdul Hamid, um afroamericano que se dizia egípcio, cuja vida se estendeu do ano de 1903 a 1938 (GILROY, 2007). Fundou em Nova Iorque o Universal Holy Temple of Tranquility ${ }^{13}$, cujo nome não convinha com seu comportamento agressivo - foi preso por esfaquear um seguidor de Marcus Garvey. Sufi Abdul Hamid foi apelidado de "Black Hitler"" pela mídia, alcunha aceita por ele, pois, em seus discursos, afirmava ser o único capaz de acabar, por meio de uma guerra sangrenta, com os judeus, considerados por ele o pior tipo de branco existente. Os negros deveriam ocupar o lugar dos judeus, que espalhavam doenças e sujeira pelo mundo. Além disso, pressionava os empresários brancos nãojudeus a contratarem negros. A queda de seu avião, pilotado por ele próprio, levou ao seu óbito. Sua secretária, uma mulher branca - símbolo de subjugação do branco - sobreviveu.

Partidos políticos também tiveram apelo entre os afro-americanos. O Partido Comunista dos Estados Unidos da América, fundado em 1919, defendeu, inicialmente, que os negros se identificassem como nação e reivindicassem um Estado. Posteriormente, posicionou-se a favor de um mundo pós-nacionalista, tentando convencer seus membros a abandonarem a ideia de soberania estatal (SCOTT, 2012).

O partido elaborou estratégias para ganhar adeptos entre distintas raças, nacionalidades e etnias. Todos seriam libertados do Capitalismo, contudo, os proletários que compartilhassem traços que pudessem identificá-los como uma nação seriam considerados uma nacionalidade oprimida. Seria dado suporte para que essas nacionalidades adquirissem autodeterminação e formassem um Estadonação não capitalista, que, depois, seria desfeito. Stálin estava de acordo com a ideia de que os negros dos Cinturões Pretos dos Estados Unidos fossem considerados uma nacionalidade oprimida e não uma minoria, o que lhes dava a condição de reclamar nacionalismo e autodeterminação.

No VI Congresso Mundial da Internacional Comunista (1928), foi feita uma resolução sobre a questão do negro nos Estados Unidos, a qual propugnava a autodeterminação dos afro-americanos

13 Tradução livre: "Templo Sagrado Universal da Tranquilidade".

14 Tradução livre: "Hitler Preto". 
nos Cinturões Pretos do Sul. No entanto, o partido preferiu, no fim, apoiar a luta pelos direitos civis em vez de a formação de um Estado negro. A ideia de solidariedade entre trabalhadores deveria sobrepor-se à problemática racial, por isso, questões referentes à segregação racial não eram pautas recorrentes. O credo de que a revolução proletária era iminente, fez o Partido Comunista dar um respaldo às reivindicações por direitos, não mais para práticas nacionalistas.

O proletariado norte-americano, porém, encontrava-se afastado da máxima marxista. A segregação prevalecia sobre a união. Diversos sindicatos proibiam a associação de negros, ou deixavam suas reclamações em último plano. A Brotherhood of Sleeping Car Porters ${ }^{15}$, criada pelos empregados afro-americanos da Companhia Pullman de vagões ferroviários em 1925, foi a primeira organização trabalhista composta e liderada por negros (Asa Philipi Randolphe e Milton Price Webster) a receber autorização de funcionamento da Federação Americana de Trabalho. Atividades sindicais que envolvessem negros não podiam escapar da luta pelos direitos civis, porque as relações patrão-empregado eram atravessadas pelo racismo. Em seus comícios, a segregação era pauta contínua. Devido à relação do movimento de trabalhadores negros com a questão ligadas aos direitos civis, autores, como Paula Pfeffer (1996), chamam Asa Philip Randolphe de pioneiro do Movimento pelos Direitos Civis estadunidense.

Um dos grandes promotores da ideia "Black is beautiful"," arrolado como primeiro a enfatizar a beleza negra por autores como Scott (2012), foi o dominicano Carlos A. Cooks (1913-1966), que faleceu no Harlem, em Nova Iorque. Discípulo de Marcus Garvey, fundou o African Nationalist Pioneer Movement ${ }^{77}$, cujos objetivos eram, em prol da autodefesa e da sobrevivência: revitalização da nobreza, coragem e engenhosidade preta por meio da hegemonia de sua raça em seu lar e no estrangeiro; rejeição de teorias de melhoramento racial que não fossem produzidas pelo próprio grupo; negação de todo padrão de beleza que não representasse as características pretas como belas; concessão de apoio apenas aos representantes de sua raça quando o assunto envolvesse políticas raciais; denúncia de religiões que difundissem o mito da supremacia branca. Cooks realizava concursos de beleza para exaltar a mulher negra e combater padrões estéticos que menosprezavam a

15 Tradução livre: "Irmandade dos Bagageiros de Vagão Ferroviário".

16 Tradução livre: "Preto é lindo".

17 Tradução livre: "Movimento Pioneiro Nacionalista Africano ”. 
pessoa preta. Os concursos deveriam premiar a beleza natural, não adaptações à estética euroamericana. Fazia campanhas para que seus seguidores comprassem de outras pessoas afroamericanas (HARRIS et. al., 1992).

Um grupo inter-racial de estudantes de Chicago organizou-se, em 1942, para atuar a favor da dessegregação. Foi um dos primeiros movimentos a utilizar táticas de não-violência nos Estados Unidos, denominando-se Congress of Racial Equality ${ }^{18}$ (CORE). Firmou parceria com Martin Luther King Junior em ocasiões diversas, como no boicote dos ônibus em Montgomery. Ajudaram a organizar as "Viagens de Liberdade", que transportavam brancos e negros do Norte num ônibus em direção ao Sul, para quebrar, simbolicamente a segregação no transporte público interestadual. A primeira viagem aconteceu em 1961, de Washington para Nova Orleans. A polícia e brancos racistas responderam com brutalidades. Em meados da década de 60, o CORE abriu mão do pacifismo e assumiu uma conduta separatista.

Stokely Carmichael, Ella Baker e Bob Moses coordenaram as ações do Student Nonviolent Coordinating Committee ${ }^{19}$ (SNCC). Formado em 1960, protagonizaram inúmeros protestos sentados, nos quais ocupavam pacificamente locais interditados aos negros, objetivando o fim da lógica "Iguais, mas separados". Aguentavam agressões físicas e psicológicas sentados, sem responder ao agressor.

A expressão "Black Power" popularizou-se através do discurso de Stokely Carmichael na Marcha Contra o Medo de 1966. No final da marcha, que começara com a caminhada solitária de James Meredith de Memphis, no Tennessee, para Jackson, no Mississippi, protestando contra o sistema eleitoral daqueles estados que prosseguiam evitando o registro eleitoral de negros, mesmo após a aprovação da Lei do Direito de Voto em 1965, Carmichael pronunciou-se, após sair da cadeia e Meredith ter sido baleado. Seu discurso salientava a importância da solidariedade entre os negros e do orgulho racial, para que, unidos, alcançassem o poder de controlar e criar instituições sem esperar pela sanção do branco. O poder preto precisava atingir o patamar de força dos brancos, senão sua eficiência seria nula dentro da sociedade. Carmichael começava a duvidar do caminho demorado da não-violência (RISSMAN, 2015; PINKNEY, 1976).

18 Tradução livre: "Congresso para Igualdade Racial”.

19 Tradução livre: "Comitê de Coordenação Estudantil Não-violenta".

20 Tradução livre: "Poder Negro". 
Em Oakland, na Califórnia governada por Ronald Reagan, um grupo de afro-americanos, vestidos com suas jaquetas de couro preto, formaram uma equipe de autodefesa, com o intuito de vigiar os guetos, impedindo abusos policiais e outros tipos de violência embasada em ideais de branquitude. Huey Newton e Bobby Seale, juntos de seus companheiros, perambulavam nas ruas armados, para coibir a opressão contra o negro, não para atacar pessoas. Valeram-se da Constituição estadunidense e de leis locais, as quais permitiam o porte de armas, desde que não estivessem ocultas. As atividades expandiram-se (auxílios na alimentação, saúde e segurança da população local) e o grupo tornou-se o Black Panther Party for Self-Defense ${ }^{21}$. Ademais, os Panteras Negras tiveram um importante papel no reforço da representação e da estética negra, porque apareciam bastante na mídia com seus cabelos Black Power e um estilo de vestir próprio. O partido chegou a lançar candidatura política, mas sem sucesso. Influenciados pelo maoísmo, desejavam "All power to the people"22 (BLOOM e MARTIN JR., 2013: p.241), o que muito apavorou o governo dos Estados Unidos da América.

A mentalidade descolonizadora - ressaltada pela Conferência de Bandung - e as independências africanas no decorrer do século XX influíram sobre movimentos negros (SCOTT, 2012). Lograr a libertação dos afro-americanos dos grilhões da colonização sofrida no território dos Estados Unidos era meta perseguida, valendo-se da força ou não. Os guetos levantaram-se contra a opressão branca, exigindo, em alguns casos, a formação de um Estado-nação de base racial, em outros, respeito à diferença e verdadeira representação política.

Movimentos de nacionalismo preto adotaram distintos posicionamentos, que ambicionavam a consecução de objetivos diversos como: emigração para a África ou outra região que aceitasse o negro, ou fosse por ele governado; colonização de alguma área, para a implantação de um Estado negro; estatismo interno, ou seja, participação e representatividade negra dentro dos Estados Unidos da América; pluralismo cultural (criação de instituições próprias para o negro, em que sua diferença fosse respeitada). Pinkney (1976) afirma que houve nacionalismos pretos em um âmbito cultural, que exaltava a herança cultural afro e cobrava dos afro-americanos a valorização dessa diferença,

21 Nome original: "Partido dos Panteras Negras para Autodefesa”.

22 Tradução livre: "Todo poder para o povo". 
combustível para uma posterior revolta contra seus opressores. O Congress of Afrikan People $e^{23}$ e o Committee for a Unified Newark ${ }^{24}$ foram exemplos desse tipo.

O autor escreve que existiram grupos voltados para um nacionalismo preto educacional. Eles estavam voltados para mudanças culturais a partir da alteração das estruturas educacionais, pois pensavam que o sistema de educação do país não preparava o negro para a libertação. Entre esses grupos estavam: Institute of Black World ${ }^{25}$ (Atlanta) e o Black Educational Center ${ }^{26}$ (Washington).

O nacionalismo preto de cunho religioso é outra categoria, conforme Pinkney (1976). Enfatizava transformações na maneira de crer dos afro-americanos, porque isso contribuiria com a libertação espiritual, o que poderia resultar em uma maior consciência sobre a realidade material. A Nação do Islã e o Shrine of the Black Madonna ${ }^{27}$ são exemplos desse nacionalismo.

O nacionalismo preto revolucionário seria aquele que clama por revolução, almejando o fim do racismo, imperialismo, capitalismo, entre outros. Alguns desses grupos combinavam nacionalismo preto com Marxismo, Leninismo e Maoísmo. Alguns movimentos desse estilo foram o Partido dos Panteras Negras e a League of Revolutionary Black Workers ${ }^{28}$.

\section{ELIJAH, FARD E A NAÇÃO DO ISLÃ}

A história da Nação do Islã é dividida por autores como Maboula Soumahoro (2008), em dois períodos: Primeira e Segunda Ressurreição. O enfoque aqui centra-se na Primeira, delimitada entre a fundação da seita em 1930 pelo mabdi Fard e a morte de seu mensageiro, Elijah Muhammad, em 1975. A Segunda Ressurreição engloba os conflitos sucessórios após a morte do honorável ministro entre, especialmente, Wallace D. Muhammad - filho de Elijah - e Louis Farrakhan, um dos

23 Tradução livre: "Congresso da Pessoa Afrikana".

24 Tradução livre: "Comitê por uma Newark Unificada".

25 Tradução livre: "Instituto do Mundo Preto".

26 Tradução livre: "Centro para a Educação Negra".

27 Tradução livre: "Templo da Madona Preta”.

28 Tradução livre: "Liga dos Trabalhadores Negros Revolucionários". 
colaboradores mais expressivos depois do afastamento de Malcolm X. Sherman Jackson (apud SOUMAHORO, 2008) fala de uma Terceira Ressurreição após a queda das torres gêmeas em 11 de setembro de 2001, na qual os muçulmanos pretos tiveram de lidar com o aumento da perseguição ao Islamismo, além da questão racial.

Soumahoro (2008) subdivide a Primeira Ressurreição em 4 estágios. Entre a aparição (1930) e o desaparecimento (1934) de W. D. Fard, o fundador da seita, o autor delimita o primeiro estágio, marcado pela tradição oral. O segundo engloba os anos 1934-1951, quando Elijah Muhammad assumiu o posto máximo de honorável ministro, enfrentando a oposição e impondo sua interpretação das lições de Fard.

A conversão de Malcolm X inaugurou o terceiro estágio (1951-1964), caracterizado pelo enorme crescimento do número de membros, devido ao aumento do número de comícios e da potente oratória do novo acólito. A Nação do Islã expandiu seu raio de ação pelo território estadunidense, despertando a atenção da mídia. Do afastamento de Malcolm X até a morte de Elijah é o quarto estágio, no qual preponderaram as disputas internas diante da saúde debilitada do mensageiro de Alá, que o distanciou dos púlpitos.

Ao fundar o Allab Temple of Islam² (nome da Nação do Islã até 1933), em 1930, o mahdi - Alá encarnado - tinha o intuito de conduzir o negro de volta à sua religião oficial. Ele mesclou suas ideias ao Islamismo. Surgiu uma religião heterodoxa, não reconhecida por muitos muçulmanos ortodoxos, onde o preto assume um caráter divino, pois descendente direto de Alá, o maior de todos da nação preta asiática da Tribo de Shabazz, enquanto o branco fora criado por Yakub, um cientista louco demoníaco membro da mesma tribo (MUHAMMAD, 1965, cap. 18).

Fard, o mahdi, segundo a crença da Nação do Islã (MUHAMMAD, 1965; 1972a; 1972b; 1973; 1975), veio à Terra em uma missão messiânica-milenarista de despertar o povo original, os muçulmanos pretos da Tribo de Shabazz, com o auxílio de seu profeta, Elijah Muhammad. No milenarismo messiânico, “a imaginação religiosa fomenta um deus renovado ou até mesmo um novo deus contestatário da ordem social e religiosa estabelecida ou dominante, atestatário de uma nova maneira de encarar ou mesmo de implantar o reino de um novo deus num homem novo"

29 Tradução livre: “Templo do Islã de Alá”. 
(DESROCHE, 1985, p. 51). Tal concepção religiosa, pode desdobrar-se em uma revolução, ou movimento de resistência, distinguindo-se da utopia por possuir deus, ou algum ser de aura divina, como peça central.

Entre os islamitas, o madismo é o tipo de milenarismo mais comum. Séculos antes de Fard, outras pessoas já haviam alegado ser o mabdi, palavra cujo significado é "guiado por Alá no rumo certo": Abu Muslim (ano de 746), Abdu Adg Alá (908), Al Hakim (1023), etc. Esse ser, que na Nação do Islã se confunde com o próprio Alá, consubstancia a esperança numa outra ordem social e religiosa, distinta daquela em vigor, a qual pode ter sido produto de algum fatalismo religioso anterior. Ele surge para guiar o povo rumo a um mundo melhor, reivindicando a liberdade de todos os tipos de sujeição e a salvação de um aniquilamento histórico-cultural, bens esses de importância vital para uma vida digna. (DESROCHE, 1985; LANTERNARI, 1974).

Os movimentos messiânicos, portanto, abrangem a presença de um profeta-guia (por vezes, a figura de um verdadeiro messias em forma humana, com a função de regenerar o povo; continuar o mito; restaurar a ordem; recriar o mundo) incentivado por alguma visão ou revelação a fundar um culto embasado em um mito de origem. A revelação provém da ação de um ser supremo, ou outra entidade mística, que iniciam seu arauto nesses saberes mitológicos. Entre os conhecimentos revelados está o de um mito de retorno às origens, que instiga a espera pela era de ouro existente outrora, ou seja, o futuro iminente guarda - para os escolhidos - a volta para uma situação paradisíaca experimentada num tempo mitológico pretérito. A instauração do paraíso, anunciada pelas profecias escatológicas e apocalípticas, dar-se-ia através de "catástrofes, retornos dos mortos, subversão da ordem (eventualmente expulsão dos brancos [no caso de profecias de povos nãobrancos que sofreram o processo de colonização], fim do mundo e sua regeneração, isto é, início de uma era de opulência e de beatude" (LANTERNARI, 1974, p. 321).

Elijah, ao se deparar com a exclusão e o não-pertencimento ao povo estadunidense, necessitou empreender a tarefa de reelaborar sua identidade, de reinventar a sua história com o intuito de transformar sua condição e a de seus irmãos. A identidade é um processo contínuo de inventar e reinventar a própria história, em que o eu se diferencia do outro. Isto ocorre 
principalmente nos momentos de crise de pertencimento, sendo que o anseio por identidade vem do desejo de segurança (BAUMAN, 2005).

Elijah perdeu o emprego em 1929. Começou a beber após longo período desempregado. A situação aviltante fê-lo ir atrás de ajuda em organizações voltadas para o auxílio ao negro. Entrou em contato com a Associação Universal para o Progresso do Negro, sob comando de Marcus Garvey, e com o Templo Americano da Ciência Moura, fundado por Noble Drew Ali (EVANZZ, 1999).

Um ano depois, continuava sua procura por reabilitação, foi até um amigo de seu pai, Abdul Mohammad - antigo membro do Templo Americano da Ciência Moura e, naquele momento, seguidor de W. Fard Muhammad -, junto de seu irmão, aspirando obter respostas para seus dilemas. Fard havia fundado o Templo do Islã de Alá em 1930, com o intuito de ressuscitar o preto e conduzi-lo de volta à sua religião oficial. Ele mesclou suas ideias ao Islamismo. Surgiu uma religião heterodoxa, não reconhecida por muitos muçulmanos ortodoxos, onde o negro assumiu um caráter divino (EVANZZ, 1999).

Soumahoro (2008) afirma que Fard apareceu nos Estados Unidos na data simbólica de 4 de julho de 1930, dia da independência do país num ano no qual a crise econômica perdurava. A falta de fontes sobre Fard o tornou uma figura envolta em dúvidas. Acredita-se que ele tenha nascido em 1877, em algum local fora dos Estados Unidos. Seu nome permanece um mistério, sendo chamado de diversas maneiras: Farrad Muhammad; F. Mohammad Ali; Professeur Ford; Wali Farrad; W. D. Fard; Wallace D. Fard Muhammad; Wali Dodd Fard; Wallace D. Ford; Fred Dodd; Fard Muhammad; George Farr ${ }^{30}$.

O discurso oficial da Nação do Islã diz que o mahdi era originário de Meca, contudo outros autores (EVANZZ, 1999; LINCOLN, 1961; SOUMAHORO, 2008) desacreditam. Conforme os autores, Fard podia ter sido um jamaicano, filho de um islamita sírio; um palestino militante dos direitos raciais na Índia, África do Sul e outros lugares do mundo; um rico homem coraixita; um exdiplomata do Reino do Hejaz, que abandonara o cargo para dedicar-se a salvação da Tribo perdida de Shabazz; um neozelandês de descendência inglesa e paquistanesa; um estadunidense cujos pais eram havaianos ou polinésios; um imigrante ilegal que entrou nos EUA pelo Canadá.

30 Nesta dissertação se opta pela maneira como Elijah Muhammad se refere ao seu mestre em seus livros. 
Vasculhando os supostos nomes, os autores (EVANZZ, 1999; LINCOLN, 1961; SOUMAHORO, 2008) acreditam que Fard possa ter sido, a partir de 1921, membro da loja maçônica de Nova Iorque, Theosophical Society ${ }^{11}$, e, posteriormente, da Associação Universal para o Progresso do Negro. Teria sido preso de 1926-1929 por pequenos delitos, seguindo, depois, para Chicago, onde ele foi membro do Templo Americano da Ciência Moura e frequentou a mesquita ahmadi municipal.

Em Chicago, Fard teria trabalhado como vendedor de seda. O trabalho de porta em porta possibilitou a ele aproximar-se da vizinhança afro-americana, mulheres principalmente. Dizia-se detentor de poderes de cura e recomendava aos seus clientes que se abstivessem dos alimentos fornecidos pelos brancos, pois, por serem demasiados gordurosos, envenenavam o sangue negro. Alterar a alimentação é, segundo Kepel (apud SOUMAHORO, 2008), uma ruptura com o modo de vida estadunidense branco, sendo uma primeira atitude para o desenvolvimento de uma mentalidade de pertencimento comunitário.

Seu carisma, aliado à sua fama de curandeiro, o tornou popular na comunidade negra de Chicago. O aumento da demanda por visitas domiciliares fez Fard buscar um local, onde as pessoas pudessem ir ouvi-lo ou consultá-lo. O primeiro templo foi fundado em Detroit.

Randolph Hohle (2013) explica que o nacionalismo preto ganhou prestígio na década de 1930, atraindo negros que, anteriormente, faziam parte de organizações de classe e partidos políticos (Partido Comunista, por exemplo) com o objetivo de lograrem seus direitos. "Detroit, Michigan, em particular, teve muitos grupos nacionalistas pretos competindo por influência. [...] Dos muitos grupos nacionalistas pretos da década de 1930, apenas a Nação do Islã sobreviveu” 32 (Op. Cit., p. $85)$.

A presença de vários grupos nacionalistas pretos em Detroit e Chicago se deu porque ambas as cidades receberam um afluxo enorme de afro-americanos desde o início do século XX. Eles estavam abandonando o Sul fortemente racializado com a esperança de refazerem suas vidas em um suposto Norte acolhedor e próspero. A maioria saiu de zonas rurais rumo às zonas urbanas que mais cresciam à época. Milton Sernett (p. 3, 1997) explica que "A cidade tornou-se a arena crítica na qual o

31 Tradução livre: "Sociedade Teosófica".

32 No original: "Detroit, Michigan, in particular, had several black nationalist groups competing for influence. [...] Of the many black nationalist groups of the 1930s, only the Nation of Islam survived". 
Cadernos de Estudos Sociais e Políticos, Rio de Janeiro, vol. 7, n 13, 2017

esforço dos afro-americanos de encontrar a "Terra Prometida" aconteceu"33.

\section{O DISCURSO NACIONALISTA PRETO DA NAÇÃO DO ISLÃ}

O conceito "raça", conforme Michael Banton (1977), foi produzido na Europa como uma categorização mutável para interpretar novas relações sociais, a qual acabou por se impor sobre os demais povos por meio do colonialismo. O autor defende que a doutrina racial não surgiu da oposição entre europeu e não-europeu, mas como uma forma de distinção sociopolítica entre os próprios povos daquele continente. A classificação racial foi produzida socialmente ao longo da história e imposta ao outro para distinguir as qualidades morais, biológicas e políticas de cada categoria. Inicialmente o conceito se atrelava ao local de origem da pessoa; o contato ultramarino associou a raça cada vez mais ao fenótipo, tendo em vista a expressiva miscigenação ocorrida e o desligamento dos descendentes das terras natais de seus pais. Os traços morfológicos, revestidos de representações, passaram a delinear as qualidades de cada raça. O corpo converteu-se num significante sobre o qual se condensa subjetividades e normatividades consoante a classificação racial - sendo que as categorias de raça variam no espaço-tempo, assim como os significados associados aos significantes referentes a essas categorias. No século XX e XXI, o genótipo ganhou relevância para a definição da raça, ou seja, a representação racial ultrapassou o campo do visível, adentrando o plano molecular e o virtual-tecnológico, sendo a engenharia genética tachada por alguns estudiosos de "Nova Eugenia" (SILVA, 2009).

A Nação do Islã foi uma dentre tantas organizações de afro-americanos a lutar pela reformulação da autoimagem da raça negra. A condição subalterna ao qual fora lançado o negro durante a vigência do escravagismo nas Américas impactava a representação sobre ele na mentalidade da população, não importando a tonalidade da pele. Demetrius Eudell (2014) assevera que a escravidão estruturou a concepção das sociedades americanas, sendo ela uma instituição básica do

33 No original: "The city became the critical arena in which the struggle of African Americans to find the "Promised Land" took place". 
sistema econômico, social, político e legal das colônias europeias, logo, influenciando a formação dos Estados que posteriormente se independentizaram. Distintamente dos sistemas escravistas dos reinos islâmicos e africanos, "Apenas nesta "nação Cristã" dos Estados Unidos aos escravos seria dito que eles não eram parte da Família humana"34 (WALKER apud EUDELL, 2014, p. 96). A natureza não completamente humana concedida à pessoa de pele escura a excluía da comunidade, lhe sendo tolhido o controle sobre sua própria vida, porquanto propriedade de alguém. A secularização da ideia de "ser humano" ao longo do desenvolvimento do pensamento humanista moderno, relacionado com uma metafísica naturalista, não alterou a situação negra (EUDELL, 2014). Aquele que antes era amaldiçoado por mitos religiosos - por exemplo, descendência do maldito filho de Noé, Cam -, passou a ser, a partir de teorias surgidas entre o século XVII e o XX, de forma laica, a contraparte identitária do europeu racional. Escravizava-se o supostamente irracional, degenerado, infantil, preguiçoso, primitivo, incapaz de grandes feitos, de lograr o progresso por si (Op. Cit.). No pós-abolição, negava-se a plenitude de direitos a essas mesmas pessoas, tratando-as como cidadãs de segunda categoria. Tal maneira de pensar gerou consequências na formação da nacionalidade estadunidense e da representação do afro-americano para ele mesmo e para o não-negro.

Perante o discurso de superioridade branca incrustado na mentalidade do povo estadunidense, a atitude de alguns descendentes de africanos escravizados ${ }^{35}$, a partir do século XIX, foi de "proclamar a negritude de sua cultura e identidade" (GERSTLE, 2008, p. 440). Líderes negros conclamaram seus irmãos para reivindicarem melhorias. Organizações diversas, de cunho religioso ou não, formaram-se com o intuito de prestar assistência aos negros, desenvolvendo uma solidariedade racial, além de promover a autoestima destruída pelos anos sob o jugo da escravidão e do racismo.

34 No original: "only in this "Christian nation" of the United States would slaves be told that they were not part of the human Family".

35 Tomando como pilar epistemológico as ideias de Florence Carboni e Mário Maestri (2012) acerca da potência da linguagem, devido à criação de representações, o que repercute em relações de poder e dominação, optou-se pelo uso de uma linguagem que tenta romper com um tipo de escrita colonizadora, capaz de produzir preconceitos e estereótipos. Com esse objetivo, empreguei termos como "escravizado" e "escravizador" em vez de "escravo" e "senhor de escravo", pois os primeiros remetem a uma ideia de processo histórico de dominação e exploração, enquanto os dois últimos, a uma noção de essência ontológica. 
Esses movimentos organizados são chamados de "black nationalisms", traduzidos aqui como "nacionalismos pretos". Não há uma tipologia unívoca, porque cada autor encaixa diferentes grupos ou pessoas dentro do conceito de modo diverso, conseguintemente, não se consegue definir um precursor desses movimentos de maneira veemente. Além disso, cada grupo e liderança possuem práticas, ideias e formas distintas de identificação.

O nigeriano, Essien Udosen Essien-Udon (1995), conceitua a expressão como o credo de um grupo negro de que ele possui, ou deveria possuir, um país. Ademais, os membros teriam de compartilhar uma herança cultural comum, assim como uma língua e uma religião. A identidade étnica $^{36}$ derivada desses elementos herdados é distinta daquela de outros grupos.

Eric Foner (1970) considera "nacionalismo preto" ações que almejam à afirmação de valores, tradições e heranças culturais únicas por parte dos afro-americanos. São atos de recusa de uma sociedade que os repudia, ao mesmo tempo em que há a procura de afirmar-se como diferente dos de ascendência não-africana.

O desejo de comando de seus destinos, controlando suas próprias instituições e organizações; a unidade do grupo em uma comunidade; resistência à opressão; reavaliação de si são características necessárias para que um movimento possa ser adjetivado de nacionalista preto, segundo James Turner (1969). Além disso, a comunidade negra deve se sustentar em um modelo de auxílio mútuo (por exemplo, comprar apenas do mercado de um coirmão que compartilhe características físicas e simbólicas).

Daryl Michael Scott (2012) afirma que o nacionalismo preto faz da solidariedade racial, nas diversas dimensões da vida humana (política, cultural, religiosa, econômica, etc.), o seu fator basilar, não estando preso à reivindicação de soberania ou autogoverno. A expressão refere-se à consciência de ser/sentir-se negro e valorizar-se, superando o jugo das pechas lançadas por pensamentos colonialistas, que tachavam de inferiores as pessoas de pele escura. Consoante Scott (2012), o paradigma clássico (associado principalmente aos nacionalistas pretos do século XIX, como, por exemplo, Marcus Garvey ${ }^{37}$ ) configura-se conforme velhas concepções de nacionalismo, nas quais a nação reclama um território exclusivo, almejando à autodeterminação. No modelo moderno

36 Apesar de eu pensar que as questões sobre nacionalismo preto giram em torno de aspectos raciais, alguns autores se referem à etnia ao tratarem do tema. 
(vinculado aos grupos surgidos no século XX mormente), os objetivos são mais modestos. Busca-se, além de participação na administração pública, o estabelecimento de laços de solidariedade econômica, cultural, religiosa e política. Aspira-se ao fortalecimento da comunidade negra sem a fundação de um Estado independente, isto é, quer-se algum tipo de inserção na sociedade vigente.

Consoante Edwin Redkey (1969), a expressão possui como núcleo o protesto contra o nacionalismo branco - nação ancorada em bases raciais brancas - difundido nos EUA. Convocam-se os afro-americanos para se defrontarem com a opressão, a qual os acomete coletivamente, causada por uma sociedade capitalista tomada pela branquitude. $\mathrm{O}$ aumento da solidariedade intragrupal e do poder é necessário para esse embate.

Um dos membros fundadores do Socialist Workers Party, George Breitman (1967), restringe o conceito espacialmente, declarando que o nacionalismo preto é um fenômeno estadunidense, em que os afro-americanos se unem como um povo contra as práticas de segregação existentes naquele país. Eles visam a obter liberdade, justiça e igualdade por via do controle de suas instituições políticas, econômicas e sociais. Entre os atributos centrais dos movimentos, o autor destaca: ódio à ideia de supremacia branca; independência da influência dos brancos; orgulho racial; consciência de grupo e identificação com o Terceiro Mundo.

O trinitário-tobaguense radicado no Bronx e membro de movimentos nacionalistas pretos, como o Comitê de Coordenação Estudantil Não-violenta e o Partido dos Panteras Negras, Stokely Carmichael (1971), tratava nacionalismo preto e nacionalismo africano como sinônimos, não enclausurando o conceito. O militante do Movimento dos Direitos Civis acreditava que o ápice era o Pan-africanismo, onde se alcançaria a unificação comunitária de todos os africanos e seus descendentes de mesma raça dentro da África, assim como o controle de todas as instituições que regem a vida dessas pessoas por elas mesmas.

O embate nacionalista preto ocorria no campo material e no subjetivo. A falta de controle dos afro-americanos sobre a imagem de si, projetada e percebida, é destacada por bell hooks ${ }^{38}$ (1992,

37 Jamaicano fundador da Associação Universal para o Progresso do Negro e Liga das Comunidades Africanas (UNIA), que viveu nos Estados Unidos entre 1916 e 1927. A UNIA foi um dos principais movimentos nacionalistas pretos a defender a autonomia através do retorno para a África.

38 Pseudônimo da escritora negra, Gloria Jean Watkins, escrito em letras minúsculas, pois a autora diz que a atenção deve ser dada à mensagem, não à pessoa do autor ou autora. 
p. 4) como "as fissuras em nossos psiquismos são os espaços onde a cumplicidade negligente, raiva autodestrutiva, ódio e desespero paralisante entram "39. A autora acusa a mentalidade estadunidense de estar dominada pelo ideal de supremacia branca, o que se reflete na institucionalização de imagens opressoras sobre a negritude através dos meios de comunicação de massa. Bell hooks salienta que supremacia branca não é a existência de preconceito apenas, todavia, sim, todo um sistema de dominação e subjugação do não-branco através de instituições embasadas em representações que depreciam o negro e as demais raças vindas de fora da Europa. A libertação do negro exige a descolonização do imaginário para que haja a produção de uma identidade positiva negra, respaldada em representações construídas por eles mesmos, sem estarem submetidas à lógica de dominação racista.

A luta ideológica consiste na tentativa de obter um novo conjunto de significados para um
termo ou categoria já existente, de desarticulá-lo de seu lugar na estrutura significativa. Por
exemplo, é justamente por conotar aquilo que é mais desprezado, despossuído, ignorante,
incivilizado, inculto, maquinador e incompetente que o termo "negro" pode ser contestado,
transformado e investido de um valor ideológico positivo. O conceito de "negro" não é
propriedade exclusiva de qualquer grupo social específico ou discurso isolado. [...] Esse
processo tem consequências e implicações concretas na maneira como a formação social
como um todo se reproduz ideologicamente. A luta em torno de "negro", caso este se torne
forte o suficiente, pode impedir a sociedade de se reproduzir funcionalmente daquela forma
antiga (HALL, 2013, p. 213 e 215).

A dinâmica dos signos atinge diretamente as relações sociais e as instituições, induzindo formas de interação e de afetação. Sua desconstrução quebra a reprodução das relações.

A difusão da cultura branca nos bairros negros fortalecia a autoimagem negativa carregada pelo afro-americano. Os guetos negros detinham duas dimensões:

As dimensões objetivas do gueto urbano americano são: moradia superpopulosa e deteriorada; alta mortalidade infantil, crime e doença. As dimensões subjetivas são: ressentimento, hostilidade, desespero, apatia, autodepreciação e, sua irônica companhia, a mania de grandeza compensatória ${ }^{40}$ (CLARK, 1967, p. 11).

39 No original: "the gaps in our psyche that are the spaces where mindless complicity, self-destructive rage, hatred, and paralyzing despair enter".

40 No original: "The objective dimensions of the American urban ghettos are overcrowded and deteriorated housing, high infant mortality, crime, and disease. The subjective dimensions are resentment, hostility, despair, apathy, selfdepreciation, and its ironic companion, compensatory grandiose behavior". 
Além dos problemas físicos enfrentados, o imaginário, permeado por ideais colonizadores, agregava uma subjetividade nociva à população. Os negros se viam como vítimas de si mesmos e, por consequência, nutriam a vontade de se branquear, ao menos culturalmente.

O nacionalismo preto empregava símbolos ligados à raça e, no caso da Nação do Islã, à religião para montar um discurso que desenvolvesse a autoestima negra. O revisionismo histórico, calcado em mitos, buscava explicar o sofrimento do negro, ao mesmo tempo em que o exaltava como um ser divino. Considerar o branco demônio era uma "representação da branquitude que não é formada como reação aos estereótipos, mas emerge como uma resposta a dor traumática e a angústia que persiste como uma consequência da dominação racista branca "*1 (hooks, 1992, p. 169), ou seja, o outro é demoníaco, não por causa dos estereótipos produzidos sobre o preto, mas porque causou-lhe traumas. A manipulação do conhecimento, disseminado nos templos e nas escolas ligadas ao movimento, servia para enfraquecer a influência da cultura branca hegemônica que invadia os guetos através dos meios de comunicação de massa, da cultura popular e do sistema formal de educação (CLARK, 1967; ESSIEN-UDON, 1995).

O líder da Nação do Islã fundamentou sua doutrina em uma narrativa trágica e redentora, a qual servia de alternativa a ideologias como o comunismo, o integracionismo em bases burguesas da NAACP, o assimilacionismo de Booker T. Washington, etc. (EYERMAN, 2003). Por meio dessa narrativa, se reinterpretou a história e a memória coletiva dos afro-americanos para se criar uma nova identidade preta desatrelada de representações negativas, o que também afeta o comportamento e o modo de pensar dos indivíduos.

A reinterpretação, ou melhor, a reconceituação da história foi assim combinada com um programa muito prático para mudança de comportamento, que se construísse a partir da estrita execução de autodisciplina e visasse a transformar hábitos derivados da escravidão, que asseguravam a continuação da subordinação. Esse programa fornecia um "ethos" e novos hábitos; prescrevia um conjunto de comportamentos e uma estrutura de interpretação e avaliação, através da qual o indivíduo, com o suporte do coletivo, poderia ser, ao menos parcialmente, resgatado aqui e agora ${ }^{42}$ (EYERMAN, 2003, p. 172).

41 No original: "representation of whiteness that is not formed in reaction to stereotypes but emerges as a response to the traumatic pain and anguish that remains a consequence of white racist domination.". 
A base doutrinal do movimento está no Islamismo, pois esse é tido como uma religião verdadeiramente negra, dado que a maioria dos africanos, segundo Elijah Muhammad em Message to the blackman in America (1965), era islâmica, por conseguinte, Elijah afirma que Fard acreditava que os afro-americanos seriam naturalmente maometanos. Já o Cristianismo, para Fard (MUHAMMAD, 1965), seria um culto branco responsável pelo sofrimento dos seres humanos de tez escura. A igreja cristã jamais se opôs à escravidão, inclusive, apoiou a exploração do trabalho compulsório. Ela iludiu e conspurcou o negro ao convertê-lo a uma religião falsa, cuja interpretação dos textos sagrados era controlada pelos brancos para evitar o acesso à verdade e revoltas negras. Somente o Islã seria verdadeiro, todos os profetas - Jesus, Moisés, Maomé, etc. - eram islamitas em realidade e pregavam o retorno de Alá, que assumiu forma imanente de homem: Fard, o mabdi. Em várias passagens dos livros, Fard é chamado de Alá, como, por exemplo: “Apenas Alá, nosso Amado e Mais Misericordioso Deus, que veio, na pessoa do Mestre Fard Muhammad em 1930, nos aceitará"43 (MUHAMMAD, 1974, cap. 9, \2).

Elijah Muhammad, no prefácio do livro “Our saviour has arrived” (1975), informava ensinar a sabedoria suprema revelada a ele pelo próprio Alá, personificado em Wallace Fard. Avisava que nenhum outro homem podia transmiti-la, porque ele foi o encarregado desta mensagem. Com o apoio de Alá, ele levaria ao inimigo sua condenação. O prefácio já coloca um homem preto como o único detentor da verdade suprema capaz de sentenciar o branco ao inferno. Os demais movimentos negros, Elijah dizia à época: "têm boas intenções, mas eles apenas não têm os instrumentos corretos para trabalhar e eles não sabem como usar os instrumentos, porque não foram designados para o trabalho"44 (MUHAMMAD, 1965, cap. 133, \ 28). No decorrer dos livros, o afro-americano abandona a posição subalterna ao qual fora relegado dentro do discurso racializante elaborado pelo

42 No original: "The reinterpretation, or rather reconceptualization of history was thus combined with a very practical program for changing behavior, one that built on strictly enforced self-discipline, and aimed at transforming habits stemming from enslavement which ensured continued subordination. This program provided an "ethos," and new habits, proscribed sets of behaviors, and a framework of interpretation and evaluation, through which the individual with the support of the collective could be, at least partially, redeemed here and now".

43 No original: "Only Allah, our Loving and Most Merciful God Who came in the person of Master Fard Muhammad in 1930, will accept us".

44 No original "have good intentions, but they just don't have the right instruments to work with, and they do not know how to use the instruments, since they were not appointed to do the job". 
euro-americano, passando a representar-se como descendente do próprio Alá e sua tribo preta de Shabazz, guiado pela sabedoria do profeta e do mahdi.

Elijah reconhecia sua situação de não-membro da nação em seu texto: "vocês não são nacionais; vocês não são cidadãos deste país! O único cidadão aqui é branco. Vocês não são americanos; o único americano é branco. Vocês não podem ser americanos a não ser que vocês sejam brancos. Mas você pode ser um escravo dos americanos ${ }^{\sharp 5}$ (MUHAMMAD, 1975, cap. 11, \ 42). A identidade nacional não abarcou os inferiorizados pelas representações sustentadas pelos construtores da nação dos Estados Unidos. Elijah (Op. Cit.) ressaltava que essa exclusão se mantinha, por isso, o negro continuava a ser explorado pelo branco em condições semelhantes à de um cativo, destarte, caberia aos afro-americanos se organizarem em prol de mudanças. Teriam de montar uma economia própria para poderem sustentar, futuramente, um Estado próprio, que poderia ou não ser na África. Cabe lembrar que o programa de contra inteligência do FBI, COINTELPRO, investigou a Nação do Islã e outros movimentos negros, como os Panteras Negras, por praticarem atos tachados de antiamericanos.

No capítulo onze de "Our Savior has arrived", Elijah (MUHAMMAD, 1975, \$42) pedia o retorno dos Pretos para seu país nativo fazendo menção ao continente africano, região de alta concentração de pretos de onde se retirou os trabalhadores escravizados levados para a América, tratando-o como um todo homogêneo, porém valorizado positivamente: "You have to make yourself now a citizen of Africa, your native country ${ }^{\prime 46}$. Essa homogeneidade africana foi parcialmente herdada do imaginário europeu colonial, que pensava a África como amorfa, de regiões e povos indistintos em sua condição primitiva. "O termo África é [...] uma construção moderna, que se refere a uma variedade de povos, tribos, culturas e línguas cujo principal ponto de origem comum situava-se no tráfico de escravos" (HALL, 2013, p. 34). A Libéria havia sido erigida naquele continente para abrigar negros retirados dos Estados Unidos, talvez isso fizesse Elijah enxergar naquele continente uma possibilidade de criação do Estado que ele reivindicava. Além disso, outras lideranças afro-

45 No original: "You are no national; you are no citizen of this country! The only citizen here is white. You are not American; the only American is white. You can't be Americans unless you are white. But you can be a slave for the Americans".

46 Tradução livre: "Vocês têm de fazer vocês mesmos agora um cidadão da África, seu país nativo". 
americanas anteriores à Nação do Islã, como Alexander Crummell, Henry McNeal Turner e Marcus Garvey, haviam desejado e, até mesmo, tentado pôr em prática tal ideia de emigração para formação de um Estado negro na África.

O desejo de fazer-se cidadão africano aparece nesse que é o último dos livros de Elijah, entretanto, em seus textos anteriores, ele assume uma postura aberta a outras medidas, aceitando a possibilidade de que alguns Pretos optassem por permanecer nos Estados Unidos, ou o recebimento de boas terras, providenciadas pelos antigos senhores escravizadores. Ele resumia os desejos dos islamitas pretos bradando em nome de todos:

Nós queremos liberdade. Nós queremos uma ampla e completa liberdade. Nós queremos justiça. Justiça igual sob a lei. Nós queremos justiça aplicada igualmente a todos, independentemente da crença, classe ou cor. Nós queremos igualdade de oportunidade. Nós queremos ser membros iguais, com o melhor da sociedade civilizada. Nós queremos que nosso povo na América, cujos pais ou avós foram descendentes de escravos, sejam consentidos a estabelecer um estado separado, ou território deles mesmos - neste continente ou em outro. Nós acreditamos que nossos antigos mestres de escravos são obrigados a fornecer tal terra e que a área deve ser fértil e mineralmente rica. Nós acreditamos que nossos antigos mestres escravizadores são obrigados a manter e suprir nossas necessidades neste território separado pelos próximos 20 ou 25 anos, até nós estarmos aptos a produzir e suprir nossas próprias necessidades. [...] Nós queremos que todo o homem e mulher negro tenha a liberdade de aceitar ou rejeitar ser separado dos filhos dos mestres de escravos e estabeleça uma terra para eles mesmos ${ }^{47}$ (MUHAMMAD, 1965 , cap. $74, \$ 1,2,3,4,5)$.

Permanecer ou separar-se era uma atitude voluntária, no entanto, ele aconselhava aqueles que quedassem em território estadunidense a organizarem-se de modo cooperativo para escapar do domínio ideológico branco e alcançar uma integração justa. Uma classe política negra precisaria formar-se para defender os interesses da raça no congresso e demais órgãos governamentais. Os

47 No original: "We want freedom. We want a full and complete freedom. We want justice. Equal justice under the law. We want justice applied equally to all regardless of creed, class or color. We want equality of opportunity. We want equal membership in society with the best in civilized society. We want our people in America whose parents or grandparents were descendants from slaves to be allowed to establish separate state or territory of their own - either on this continent or elsewhere. We believe that our former slave master are obligated to provide such land and that the area must be fertile and minerally rich. We believe that our former slave-master are obligated to maintain and supply our needs in this separate territory for the next 20 or 25 years until we are able to produce and supply our own needs. [...] We want every black man and woman to have the freedom to accept or reject being separated from the slave-masters' children and establish a land of their own". 
anseios expressos delineavam uma posição contrária ao integracionismo anti-racialista ${ }^{48}$, ao branqueamento, à assimilação cultural, pois Elijah acreditava “a oferta de integração é hipócrita e é feita por aqueles que que estão tentando enganar os povos pretos para acreditarem que, depois dos 400 anos como inimigos da liberdade, justiça e igualdade, eles se tornaram, de repente, amigos" (MUHAMMAD, 1965, cap. 74, \9). A permanência naquele país não deveria perpetuar condições de dependência, submissão e exploração.

De certo modo, reclamava-se a formação de um Estado que prezasse pelas diferenças de sua população, ao invés de instituir uma uniformização cultural consoante o paradigma de Estado-nação modernos, dentro dos EUA, para tornar verdadeiro cidadão o Preto que lá ficasse. Todavia, a intenção de erigir um Estado oficialmente muçulmano preto inscrevia o pensamento da Nação do Islã numa lógica estatal moderna de separação de acordo com raça.

O nacionalismo preto da Nação do Islã reivindicava um território para o autogoverno da população preta, onde fosse possível a apropriação do espaço e a administração sem nenhum tipo de influência colonialista. Almejava a infundir uma solidariedade entre seus membros para consolidar uma comunidade dotada de autonomia, capaz de gerir seu funcionamento. A reavaliação de si a partir do discurso mitológico impulsionava um fortalecimento da autoestima, necessária para cristalização de um grupo de resistência. O orgulho racial era escudo e espada contra um imaginário repressor, o qual instigava o desejo de branqueamento nos não-brancos. A fé num deus preto congregava, abrindo caminho para uma possível superação da dominação branca. A descolonização da mente não implicava um apagamento completo da cultura norte-americana de suas mentalidades, assim como

$48 \mathrm{O}$ antirracialismo era uma visão defendida por escritores como Jean Toomer e outros expoentes do Renascimento do Harlem (WOODSON, 1999), cuja premissa básica sustentava a ideia de que não havia diferenças entre os seres humanos, logo, a integração dos cidadãos estadunidenses deveria ser feita se apagando os marcadores sociais atrelados à concepção de raça no país. O antirracismo (Ibidem) divergia, no entanto, não se posicionava de maneira diametralmente oposta, porque arguia a favor da inserção racial; considerando, porém, o peso carregado por cada um dos grupos formadores da nacionalidade estadunidense ao longo da história. Embora se quisesse o fim da desigualdade social e jurídica, esse passado persistia, influindo sobre a constituição do sujeito psíquico das pessoas, não podendo ser descartado. Os significados atribuídos aos caracteres físicos intervinham diretamente nas relações interpessoais, por conseguinte, o antirracismo combatia o preconceito sem cerrar os olhos aos marcadores raciais, ainda mais em um período marcado pela influência do racismo científico.

49 No original: "that the offer of integration is hypocritical and is made by those who are trying to deceive the black peoples into believing that their 400-year-old open enemies of freedom, justice and equality are, all of a sudden, their friends". 
não acarretava em uma retomada de um simbolismo étnico puro anterior ao tráfico negreiro, ou da adoção das práticas e costumes de algum país africano contemporâneo.

Elijah enfrentava a supremacia branca estrutural sem apagar os marcadores atrelados à raça. Pelo contrário, ele destacava os caracteres afro-americanos, atribuindo-lhes ares divinos. De certo modo, seus livros subvertiam o imaginário sociopolítico americano.

Wunenburger (2007) afirma que entre os ingredientes da confecção do imaginário estadunidense está um maniqueísmo ontológico e moral. Os cidadãos brancos dos Estados Unidos, sob influência de uma estrutura de base calvinista, percebem-se como os eleitos do novo reino de Deus na terra, conseguintemente, como míticos homens bons. Cabe a eles enfrentarem o mal externo - o Diabo, o outro hostil - e o interno - as nódoas existentes dentro do próprio grupo. O bem, sempre vencedor, nega ou destrói o outro hostil; resgata/salva os males internos, devolvendolhes a bondade. A Nação do Islã apropriou-se do maniqueísmo estadunidense, refazendo-o de um modo em que o bem estava no muçulmano preto, cuja antropogênese provinha dos atos de Alá, uma das deidades originais. Era o negro quem teria sua essência ressuscitada e sobreviveria ao juízo final para guiar um mundo livre das maldades das pessoas brancas.

A tentativa de subversão ontológica deu-se por via da compreensão do simbolismo e de seu funcionamento. Castoriadis (1982) diz que o simbolismo não se constitui livremente, sendo influenciado pelos elementos da natureza e da história. As conexões entre significantes e significados podem ser alteradas caso se compreenda essas ligações, afirma o autor. Ao compreender que a ordem simbólica dos Estados Unidos não era neutra, mas, sim, permeada pela branquitude, Elijah Muhammad deslizou os sentidos, mudando os significados associados aos significantes raciais. No entanto, essa mudança não se constituiu de maneira livre, tendo sido influenciada pelo simbolismo ao qual eram expostos à época: Racismo Científico segregação, Nacionalismo, Esoterismo, etc. Desse modo, a subversão ontológica não se realizou, pois manteve-se presa a ideais colonizadores iluministas e cientificistas.

No capítulo onze (MUHAMMAD, 1975) é explicada a cosmogonia da Nação do Islã. Em meio a um universo mergulhado em completa trevas, surgiu um átomo de vida preto, porquanto não havia luz, nem quaisquer outras cores. O desenvolvimento dos átomos originou os elementos que 
compõem o universo. Em certo instante, Alá autocriou-se e, então, iniciou-se a Tribo de Shabazz, formada pelos homens originais pretos criados através do esperma do primeiro ser, lançado na escuridão do universo. Por ser deveras antiga a existência da tribo, não há registros exatos de seu surgimento. O livro declara que o "Black man” surgiu há mais de sessenta e seis trilhões de anos. A crença na origem comum, Poutignat e Streiff-Fenart (2011) alegam, serve para naturalizar e reificar atributos como marcadores de pertencimento a um grupo.

Entre os primeiros homens encontrava-se Yakub. Dotado de alta inteligência, ele foi capaz de fazer humanos de outras cores a partir de experiências com o barro, concebendo por último apenas seis mil anos atrás - o branco. A raça caucasiana é descrita da seguinte maneira por Elijah: “Os demônios feitos por Yakub eram realmente pálidos, com olhos bem azuis, que nós pensamos ser a cor mais feia para olhos humanos. Eles foram chamados Caucasianos - que significa, de acordo com alguns intelectuais árabes, aquele cujos efeitos maléficos não se restringem a si apenas, mas afetam os outros " ${ }^{\prime 50}$ (MUHAMMAD, 1965, cap. 56, \ 98). Demonstrava-se desdém pelos traços fenotípicos da outra raça, ao mesmo tempo em que se associou o nome "Caucasiano" à maldade, colocando-os como fonte dos problemas para si e para os demais. As representações negativas foram retiradas dos traços negroides para serem atiradas nos caucasoides, infamando o outro para se elevar.

A genealogia pré-adâmica da Nação do Islã foi uma tentativa, tal qual a do mito ariano ${ }^{51}$ (POLIAKOV, 1974), de estipular uma origem diferente do inimigo. Repudiou-se a origem humana bíblica. Um Preto de terras asiáticas criara Adão e Eva para executar seus objetivos sórdidos de conquista do poder. A origem dos muçulmanos pretos estava em Alá e na Tribo de Shabazz, os quais não eram europeus, nem semitas. Assim como o mito ariano que buscava a fonte do gênero humano em terras asiáticas - Índia, principalmente, de onde teria vindo os arianos indo-europeus - desligadas dos mitos semíticos, a Nação do Islã afirmava que a origem da humanidade acontecera em um local

50 No original: "The Yakub made devils were really pale white, with really blue eyes; which we think are the ugliest of colors for a human eye. They were called Caucasian - which means, according to some of the Arab scholars, One whose evil effect is not confined to one's self alone, but affects others".

51 "Ariano" deriva de "arya", "nobre" em sânscrito. Diversos pensadores, muitos deles buscando a construção de uma mitologia nacional, tentaram explicar a origem humana e situar a primeira língua a surgir. Refutaram a origem judaicocristã e atribuíram à humanidade origem em regiões asiáticas, como Índia, Cáucaso e China. Alguns mitos arianos serviram como uma forma de negar parentesco com judeus, associando a origem de uma raça a um povo mítico supostamente bem desenvolvido, cuja perfeição foi alcançada ao se estabelecerem na Europa e lá evoluírem. 
ora chamado de Ásia Oriental, ora de África, em um paraíso distinto do Éden da Bíblia. O parentesco entre Pretos e semitas inexistia. Segundo Elijah (MUHAMMAD, 1973), por mais que em alguns trechos ele compare seu povo aos judeus escravizados na antiguidade, os judeus haviam contribuído com a escravização dos Pretos e não mereciam confiança.

A Nação do Islã promoveu uma inversão do Racismo Científico, o qual hierarquizava as raças humanas, pondo o negro ora como a categoria humana mais primitiva, próxima aos macacos, ora como infra-humano. Elijah colocou o Preto como a raça originária pré-adâmica, cujos saberes e poderes mantinham a Terra um paraíso. O primeiro de todos, Alá, dotado de potência criadora, gerou vida e fundou a civilização a partir da Tribo de Shabazz. O caráter primevo da raça não a fazia primitiva, pelo contrário, era capaz, inclusive, de criar novas formas de vida humana a partir de matéria-prima comum. O branco, criado por Yakub, era produto da ciência dos Pretos, portadores de uma inteligência evoluída, e a menos agraciada das raças, porquanto maculada pelo mal, pela feiura e por sentimentos egoístas. De certo modo, o branco era o infra-humano na mitologia da Nação do Islã, porque fora feito do barro.

O pensamento científico perpassa o discurso da Nação do Islã, da antropogonia até a escatologia, mas invertendo a motivação colonial de ciências modernas eurocêntricas, como a Eugenia $^{52}$. O Preto não deveria ser extinto por via de métodos de seleção artificial que selecionassem os atributos brancos europeus como parâmetros de perfeição.

A Nação do Islã opunha-se à miscigenação, convocando seus membros masculinos a zelarem para que as mulheres não se branqueassem.

A raça branca não quer que nós destruamos sua raça através do casamento inter-racial. Eles até te matariam para protegerem suas mulheres. Você pode culpá-los? Não, culpe seu tolo eu por não ter respeito suficiente por seu próprio eu e sua própria nação da mesma maneira. Impeça nossas mulheres de tentarem se parecer com eles, pela descoloração; pela maquiagem; pelo alisamento e pintura do cabelo; pintando seus lábios, bochechas e sobrancelhas; vestindo shorts; indo seminuas em lugares públicos; indo nadar com eles e

52 Eugenia aqui é tratada como ciência, pois não é a falha e as atrocidades que dela surgiram por consequência que a excluem de ser ciência. A racionalidade, o método empírico de repetição, a objetividade, entre outras características da ciência moderna positivista marcam as teorias eugênicas. Suas mazelas foram racionalmente elaboradas, não podendo ser atribuídas somente ao campo do irracional. Não se pode eximir a ciência e a razão de seus crimes considerando seus desvios como algo puramente irracional. Pelo contrário, deve-se reconhecer as falhas da razão e, também, sua crueldade (VARGAS, 2011). 
permanecer na praia com homens. Tenha piscinas privadas para suas mulheres e as guarde de todos os homens. Impeça-as de ir em bares e tavernas, de sentar e beber com homens e estranhos. Impeça-as de sentar naqueles lugares com alguém. Impeça-as de usar linguagem suja em público (e em casa), de fumar e usar drogas ${ }^{53}$ (MUHAMMAD, 1965, cap. 33, \8-9).

O reconhecimento do Preto pelos outros grupos se daria mediante a proteção das mulheres. Deverse-ia acabar com o casamento inter-racial, pelo qual o branco se apossava das afro-americanas. $\mathrm{O}$ patriarcalismo permeava as ideias de Elijah, como ressalta Cheney (1999). A normatividade e as instituições eram elaboradas pelos homens. As mulheres, analisando o discurso de Elijah Muhammad, ocupavam um lugar submisso, sendo-lhes reservadas as funções domésticas e um comportamento rígido, fechado à interação com homens alheios à sua família, ou ao seu matrimônio. A mulher preta precisava ser controlada e "protegida" pelos Pretos para a consecução dos objetivos da Nação do Islã.

A defesa da mulher envolvia combater políticas públicas de saúde. As políticas de branqueamento, como as leis de esterilização, por exemplo, atacavam a mulher com o intuito de extinguir a nação preta nos Estados Unidos da América. Disfarçada de método de controle de natalidade, era, em realidade, de extermínio. Elijah (MUHAMMAD, 1965, cap. 35, \ 1, 2, 5) dizia:

\footnotetext{
"Fique atento com os truques que os demônios estão usando para estimular a ideia de falso controle de natalidade nas suas clínicas e hospitais [...] ESTERILIZAÇÃO NÃO É CONTROLE DE NATALIDADE [...] Eu digo: fique atento diante de ser pego neste tipo desgraçado de leis de controle de natalidade agora direcionado quase exclusivamente para as pobres e desamparadas pessoas pretas que não têm ninguém em quem confiar ${ }^{\$ 54}$.
}

53 Tradução livre: "The white race does not want us to destroy their race by inter-marrying with them. They will even kill you to protect their women. Can you blame them? No, blame your foolish self for not having enough respect for your own self and your own nation to do likewise. Stop our women from trying to look like them. By bleaching, powdering, ironing and coloring their hair; painting their lips, cheeks and eyebrows; wearing shorts; going half-nude in public places; going swimming with them and lying on beaches with men. Have private pools for your women and guard them from all men. Stop them from going into bars and taverns and sitting and drinking with men and strangers. Stop them from sitting in those places with anyone. Stop them from using unclean language in public (and at home), from smoking and drug addiction habits".

54 Tradução livre: "Be aware of the tricks the devils are using to instill the idea of a false birth control in their clinics and hospitals [...] STERILIZATION IS NOT BIRTH CONTROL [...] I say beware of being trapped into the kind of disgraceful birth control laws now aimed almost exclusively at poor, helpless black peoples who bave no one to rely on". 
As leis de controle de natalidade atacavam, pecaminosamente, o Preto através da inutilização do aparelho reprodutivo feminino mormente.

Consultas em hospitais podiam ser uma ameaça a população afro-americana. Pessoas encaminhadas para algum tipo de procedimento simples podiam passar, secretamente, por um procedimento de esterilização, saindo do hospital sem saber que seu corpo fora violado por médicos cúmplices de políticas eugênicas legalmente estabelecidas. Tais medidas começaram a ser postas em prática antes mesmo da ascensão dos partidos fascistas na Europa, sendo que alguns autores colocam o sistema de esterilização estadunidense como inspiração para os métodos nazistas de combate aos julgados indesejáveis (BLACK, 2003).

Elijah (MUHAMMAD, 1975) explica no capítulo 5 o funcionamento do tempo em ciclos de vinte cinco mil anos. Vinte quatro deidades pretas da tribo escrevem, antes do início de cada ciclo, o que acontecerá no decurso dos anos vindouros, preenchendo o tempo. A Bíblia original (não corrompida pelas fraudes das criaturas de Yakub) e o Corão contêm parte das escrituras divinas. A feitura dos brancos marcou o início de uma nova era que se estende até o presente.

Os primeiros espécimes brancos foram Adão e Eva (MUHAMMAD, 1965). A raça adâmica era constituída por pessoas devassas e dissimuladas; não respeitava Alá e os demais. O convívio difícil provocou a expulsão do paraíso, localizado na região da atual Meca. O cientista louco, Yakub, e suas criaturas foram degredados para a Ásia do Oeste, que se tornou Europa ao receber esses seres exilados, e lá viveram afastados da tribo de Shabazz por muitos anos. O batismo do continente de Europa está, portanto, associado à chegada dos demônios e ao mal. Elijah Muhammad (1965 cap. 55, $\int 110$ - 111) contou que

Os demônios feitos por Yakub foram forçados a partirem do Paraíso em direção às colinas da Ásia do Oeste (Europa) e despojados de tudo, menos da linguagem [...] Para garantir, os muçulmanos que viviam nas fronteiras da Ásia do Leste e do Oeste, foram ordenados a patrulhar a fronteira para manter os demônios de Yakub na Ásia do Oeste (agora chamada de Europa), para que a nação original do homem preto pudesse viver em paz, e os demônios pudessem estar sozinhos com eles mesmos para fazerem o que quisesse, desde que eles não tentassem cruzar a fronteira Leste ${ }^{55}$.

55 No original: "Yakub's made devils were driven out of Paradise, into the hills of West Asia (Europe), and stripped of everything but the language [...]To make sure, the Muslims, who lived along the borders of East and West Asia, were ordered to patrol the border to keep Yakub's devils in West Asia (now called Europe), so that the original nation of black man could live in peace; and the devils could be alone to themselves, to do as they pleased, as long as they didn't try 
Os caucasianos continuaram dotados de linguagem, de capacidade de significar o mundo e se comunicar. Ainda podiam ordenar a realidade de acordo com seus símbolos a despeito de estarem expulsos das terras sagradas.

Eles foram capazes de se organizarem e dominarem os Pretos durante o interregno em que Alá se retirara do plano terreno (MUHAMMAD, 1965). Foi-lhes reservado um período de teste fracassado devido à falsidade e ao egoísmo da raça - de seis mil anos de mando sobre o mundo que acabaria em 1914, entretanto, os afro-americanos "foram feitos, por completo, mentalmente mortos pelo inimigo (raça branca) ${ }^{\prime 56}$ (MUHAMMAD, 1975, cap. 5, \6), o que prolongou o domínio até os anos 60. Esse período de teste poderia ser visto como o fatalismo religioso que gerou a estrutura tomada pela branquitude à qual o Preto foi submetido, que o mabdi viria destruir (DESROCHE, 1985; LANTERNNARI, 1974).

Depois daquele período, a nação preta original daria luz a alguém, cuja sabedoria, conhecimento e poder seriam infinitos. Alguém a quem o mundo reconheceria como sendo o maior e o mais poderoso deus desde a criação do universo. E que ele destruiria o mundo de Yakub e restauraria a nação original, ou nação antiga, no poder para governar para sempre. O Poderoso é conhecido por muitos nomes. Não há alguém igual a ele. Nunca houve alguém como ele. Referem-se a ele na Bíblia como Deus, Todo-poderoso, e em alguns lugares como Jeová, o Deus dos deuses e o Senhor dos senhores. O sagrado Corão refere-se a ele como Alá, o único Deus; além dele não há nenhum deus e nada como ele; o Ser supremo; o poderoso, o sábio, o maior conhecedor, a luz, o gerador de vidas, o Mahdi (Esse é ele, quem eu conheci e por quem fui incumbido) ${ }^{57}$ (MUHAMMAD, 1965, cap. 55, $\mathbb{S}$ $60,61,62)$.

Fard é o mahdi, deus em forma humana, para Elijah. Berg (2009) salienta que foi Elijah quem chamou Fard de profeta e, depois de sua partida, de mahdi, explicando que Alá não precisava mais permanecer no plano terreno, porquanto já o havia transformado em um novo profeta. Sua chegada teria

crossing the East border".

56 No original: "have been made so completely mentally dead by the enemy (white race)".

57 No original: "After that time [período de seis mil anos], the original black nation would give birth to one, whose wisdom, knowledge and power would be infinite. One, whom the world would recognize as being the greatest and mightiest God, since the creation of the universe. And, that He would destroy Yakub's world and restore the original nation, or ancient nation, into power to rule forever. This mighty One, is known under many names. He has no equal. There never was one like Him. He is referred to in the Bible as God Almighty, and in some places as Jehovah, the God of Gods, and the Lord of Lords. The Holy Quran refers to Him as Allah, the One God; beside Him, there is no God and there is none like Him; the Supreme Being; the mighty, the wise, the best knower; the light; the life giver; the Mahdi (this is He, Whom I have met and am missioned by)". 
impulsionado a ressurreição do Preto (obtenção da verdade, da autonomia e da verdadeira religião; recuperação mental) com o conhecimento que ele trouxe e transmitiu para Elijah, incumbindo-o de repassá-lo para seu povo, o qual permanecia escravizado mentalmente. O Preto deveria ser resgatado do domínio do mal, do senhor escravizador e sua prole, recuperando sua condição original boa. As manifestações do movimento pelos direitos civis, momento derradeiro do mando branco, em que se questionou as instituições tomadas pela branquitude seria a prova da ressurreição em curso dos Pretos.

\section{CONSIDERAÇÕES FINAIS}

O nome, "Black man", carregado de novos significados, reivindicava uma nova condição que não se encaixava na nacionalidade e cidadania estadunidense, pois não eram reconhecidos, nem se reconheciam como americanos. Elijah Muhammad ironizava a categoria de não-americano no qual era posto pelo governo por manifestar-se em prol da melhoria da vida dos pretos. Por fim, aceitou que era um não-americano, porque os Pretos tinham origem racial diferente, logo, não seria o aparato estatal dos Estados Unidos quem garantiria os direitos dos descendentes da Tribo de Shabazz. A lei daquele país protegia e privilegiava, segundo o autor, apenas seus verdadeiros cidadãos, a saber, os brancos de ascendência europeia, relegando o Preto à subalternidade, sem acesso às benesses básicas que o Estado provia.

Elijah Muhammad, a despeito de não ter desempenhado um papel ativo durante as manifestações pelos direitos civis, tendo inclusive criticado aqueles que fizeram o contrário, como Martin Luther King Júnior, arrostou o racismo e a desigualdade social embasados na branquitude. A cosmovisão que pregou angariou milhares de seguidores, que, estimulados por uma outra forma de representar seus marcadores sociais da diferença, buscaram se organizar para melhorarem suas condições de vida e, quiçá, erigir um novo mundo governado pelos homens pretos originais, portadores da retidão. Apesar de não ter alterado a ontologia do conceito de "raça", ele inverteu os 
significados de suas categorias, o que serviu de base para um movimento de resistência à branquitude.

Submetido para avaliação 24 de janeiro de 2018

Aceito 23 de setembro de 2018

\section{BIBLIOGRAFIA}

ANGELL, Stephen Ward. (1992), Bishop Henry McNeal Turner and African-American Religion in the South. Knoxville: University of Tennessee Press.

BAUMAN, Zygmunt. (2003), Comunidade: a busca por segurança no mundo atual. Rio de Janeiro: Zahar.

BANTON, Michael. (1977), A ideia de raça. Lisboa: Edições 70.

BLACK, Edwin. (2003), War against the weak: eugenics and America's campaign to create a master race. New York: Four Walls Eight Windows.

BLOOM, Joshua; MARTIN JR., Waldo E. (2013), Black against empire : the history and politics of the Black Panther Party. Berkeley: University of California Press.

BREITMAN, George. (1967), The last years of Malcolm X. New York: Shocken Books.

CARBONI, Florence; MAESTRI, Mário. (2012), A linguagem escravizada: língua, história, poder e luta de classes. São Paulo: Expressão Popular.

CARDOSO, Lourenço. (2010), "Branquitude acrítica e crítica: a supremacia racial e o branco antiracista”. IN: Revista latino-americana de ciências sociais, vol. 8, n. 1., ene-jun.

CARMICHAEL, Stokely. (1971), Stokely speaks. New York: Random House. 
CHENEY, Charise. (1999), "Representin'God: rap, religion, and the politics of a culture" IN: The north star: a journal of African American religious history, vol. 3, $\mathrm{n}^{\circ} 1$. Disponível em: http://www.princeton.edu/ jweisenf/northstar/volume3/cheney.pdf Acesso em: 23/01/18.

CLARK, Kenneth B. (1967), Dark Ghetto. Dilemmas of social power. New york: Harper Torchbooks.

CORBOULD, Clare. (2009), Becoming African American: black public life in Harlem, 1919 - 1939. Cambridge: Harvard University Press.

DESROCHE, Henry. (1985), Sociologia da Esperança. São Paulo: Edições Paulinas.

ESSIEN-UDON, E. U. (1995), Black Nationalism: the search for an identity. Chicago: University of Chicago Press.

EUDELL, Demetrius L. (2014), "Black Culture in the Eighteenth and Nineteenth centuries" IN: HALTTUNEN, Karen. A companion to American cultural history. New Jersey: Blackwell Publishing.

EVANZZ, Karl. (1999), The messenger: the rise and fall of Elijah Muhammad. Westminster: Pantheon books.

EYERMAN, Ron. (2003), Cultural Trauma. Slavery and the Formation of Afro American Identity. Cambridge: Cambridge University Press.

FONER, Eric. (1970) “In search of Black History”. IN: The New York review of books. 22 de outubro.

GARNER, Steve. (2007), Whiteness: an introduction. London and New Yotk: Routledge.

GERSTLE, Gary. (2008) "Raça e nação nos Estados Unidos, México e Cuba, 1880-1940” IN: DOYLE, Don H.; PAMPLONA, Marco A. (org.). Nacionalismo no Novo Mundo. Rio de Janeiro: Record.

GILROY, Paul. (2007), Entre campos: nações cultura e o fascínio da raça. São Paulo: Annablume.

HALL, Stuart. (2013), Da Diáspora: identidades e mediações culturais. Liv Sovik (org.). Belo Horizonte: Editora da UFMG.

HARRIS, Leonard. (1989), The philosophy of Alain Locke: Harlem Renaissance and beyond. Philadelphia: Temple University Press. 
HOHLE, Randolph. (2013), Black citizenship and authenticity in the civil rights movement. New York: Routledge.

hooks, Bell. (1992), Black looks: race and representation. New York: Routledge.

HOUAISS, A. (2009), Dicionário eletrônico Houaiss da língua portuguesa. Versão 3.0. Rio de Janeiro: Objetiva.

LANTERNARI, Vittorio. (1974), As religiões dos oprimidos. São Paulo: Editora Perspectiva.

MOSES, Wilson Jeremiah.(2004), Creative Conflict in African American Thought : Frederick Douglass, Alexander Crummell, Booker T. Washington, W. E. B. Du Bois, and Marcus Garvey. New York : Cambridge University Press.

MUHAMMAD, Elijah. (1965), Message to the blackman in America. Versão digital. Disponível em: http://www.archive.org/details/MessageToTheBlackmanInAmerica Último acesso em: 21/03/2017.

(1973), The fall of America. Versão digital. Disponível em: http://archive.org/details/FallOfAmerica Acesso em: 19/01/2018.

(1975), Our Savior has arrived. Versão digital. Disponível em: http://archive.org/details/OurSaviorHas Arrived Acesso em: 19/01/2018.

OXFORD DICTIONARIES (2016). Oxford Dictionaries Online. Oxford: Oxford University Press. http://www.oxforddictionaries.com/pt/ Acesso em: 19/01/2018.

PINKNEY, Alphonso. Red, Black, and Green. Black Nationalism in the United States. New York: Cambridge University Press, 1976.

POLIAKOV, Léon. (1974), O mito ariano: ensaio sobre as fontes do racismo e dos nacionalismos. São Paulo: Perspectiva, Ed. da USP.

POUTIGNAT, Philippe; STREIFF-FENART, Jocelyne. (2011), Teorias da etnicidade: seguido de grupos étnicos e suas fronteiras de Fredrik Barth. São Paulo: Ed. UNESP.

REDKEY, Edwin S. (1969), Black Exodus. New Haven: Yale University Press.

RISSMAN, Rebecca. (2015). The Black Power Movement. North Mankato: Abdo Publishing.

SCOTT, Daryl Michael. (2012), "How Black Nationalism became sui generis" IN: Fire!!!, vol. 1, no 2. Disponível em: http://www.jstor.org/stable/10.5323/fire.1.2.0006 Acesso em: 19/01/2018. 
SOUMAHORO, Maboula. (2008), La couleur de Dieu? Regards croises sur la Nation d'Islam et le Rastafarisme, 1930-1950. Tours: Université François Rabelais de Tours. Tese de Doutorado em Inglês/Civilização.

TURNER, James. (1969) “The sociology of Black Nationalism”. IN: The Black Scholar. Dezembro.

ULLMAN, Victor. Martin R Delaney - The Beginnings of Black Nationalism. Boston: Beacon Press, 1971.

VARGAS, A. Z. (2011), “Razão, cegueira e mito”. IN: Topoi. Rio de Janeiro: v. 12, p. 284-303. Disponível em: http://www.revistatopoi.org/numero atual/topoi $22 /$ topoi $\% 2022 \% 20-\% 20$ artigo \%2016.pdf Último acesso em: 24/01/2018.

WOODSON, Jon. (1999), To Make a New Race: Gurdjieff, Toomer, and the Harlem Renaissance. Jackson: University Press of Mississippi.

YUliANI-SATO, Dwi Hesti. (2007), A comparative study of the Nation of Islam and the Islam. Bowling Green: BGSU. Dissertação de mestrado em artes, Bowling Green State University, Bowlin Green, Ohio, 2007.2 Disponível em: https://etd.ohiolink.edu/ap:10:0::NO:10:P10 ACCESSION NUM:bgsu1162806528 Último acesso em: $11 / 10 / 15$.

ZAMBONI, Marcio. (2014), “Marcadores Sociais”. In: Sociologia Especial. São Paulo: Escala, 2014. Disponível em: http://www.agenciapatriciagalvao.org.br/dossie/wpcontent/uploads/2015/07/ZAMBONI MarcadoresSociais.pdf Acesso em: 19/01/2018. 